\title{
Investigation of host and pathogen responses to estrogen in cystic fibrosis
}

\author{
Moyser Mulla*, G Lavelle, PJ McKiernan, CM Greene \\ From International Conference for Healthcare and Medical Students 2012 \\ Dublin, Ireland. 2-3 November 2012
}

\section{Introduction}

A 'gender gap' exists in Cystic Fibrosis (CF). Females acquire earlier microbial infections; have worse lung function and poorer survival rates [1]. The sex-hormone estrogen (estradiol, E2) has recently been highlighted as a key molecule responsible for the CF gender dichotomy [2]. Pseudomonas aeruginosa which colonises the CF lung and dominates at end stage disease undergoes mucoid conversion in response to E2 [2,3]. The aim of this project was to study other roles of E2 in host and pathogen responses by investigating its effects on the growth rate of Ps. aeruginosa and the expression of catalase and superoxide dismutase (SOD) in CF bronchial epithelial cells.

\section{Methods}

Growth rate of Ps. aeruginosa (PA01) in the presence or absence of E2 was measured by recording optical density $\left(\mathrm{OD}{ }_{600 \mathrm{~nm}}\right)$ at different time points and by calculating $\mathrm{cfu} / \mathrm{ml}$. Measurements of catalase and SOD gene expression in E2-treated CFBE410- airway epithelial cells were carried out using real time qRT-PCR. Results were analysed using Graphpad PRISM 5.0.

\section{Results}

E2 had no effect on the growth of Ps. aeruginosa when compared to control. The expression of catalase mRNA in CFBE410- cells in response to E2 was not altered however, there was two-fold increase in SOD gene expression in response to $10 \mathrm{nM} \mathrm{E2,} \mathrm{24hr} \mathrm{(} \mathrm{p}=0.0057)$.

\section{Conclusion}

Estradiol has no effect on the growth of Ps. aeruginosa in vitro. In CF bronchial epithelial cells although catalase

\footnotetext{
* Correspondence: moysermulla@rcsi.ie

Dept. Medicine, Royal College of Surgeons in Ireland, Education and Research Centre, Beaumont Hospital, Dublin, Ireland
}

gene expression remains unchanged, E2 increases SOD expression, potentially increasing hydrogen peroxide levels and contributing to Ps. aeruginosa mucoid conversion.

Published: 30 January 2013

\section{References}

1. Chotirmall SC, Greene CM, Harvey BJ, McElvaney NG: The Cystic Fibrosis 'Gender Gap'. InTech 978-953-51-0287-8 2012.

2. Chotirmall SC, Harvey BJ, McElvaney NG, Greene CM: Pulmonary Inflammation in Cystic Fibrosis. Current Medical Literature - Cystic Fibrosis 2011, 2:37-48.

3. Chotirmall SH, Smith SG, O'Neill SJ, Greene CM, McElvaney NG, et al: Effect of estrogen on pseudomonas mucoidy and exacerbations in cystic fibrosis. N Engl J Med 2012, 366(21):1978-86, 24.

doi:10.1186/1753-6561-7-S1-P4

Cite this article as: Mulla et al:: Investigation of host and pathogen responses to estrogen in cystic fibrosis. BMC Proceedings 2013 7(Suppl 1): P4.

\section{Submit your next manuscript to BioMed Central and take full advantage of: \\ - Convenient online submission \\ - Thorough peer review \\ - No space constraints or color figure charges \\ - Immediate publication on acceptance \\ - Inclusion in PubMed, CAS, Scopus and Google Scholar \\ - Research which is freely available for redistribution \\ Submit your manuscript at www.biomedcentral.com/submit}

